\title{
Lembaga Pendidikan Tinggi Al-Azhar: Mengenang Peradaban Islam Masa Fatimiyah (297-567 H/909- 1171M)
}

\author{
Dedi Sahputra Napitupulu dan Solihah Titin Sumanti
}

Mahasiswa Pascasarjana Universitas Islam Negeri Sumatera Utara Dosen Prodi Sejarah Peradaban Islam Universitas Islam Negeri Sumatera

Utara

dedisahputranapitupulu@yahoo.com

solihah.sumanti@gmail.com

\begin{abstract}
Al-Azhar is one of the institution's pride the Islamic Ummah. History has recorded how the existence of Al-Azhar of the early Fatimid Dynasty to this day holds a great story very interesting. Not only that, Al-Azhar also contribute on the development of civilization and Islamic intellectuals. Many scientists the great scientists who were born from there. One thing that is not less important is that it turns out that the existing educational system in Al-Azhar turned out at the adoption by the institutions which exist in Western countries. Therefore, this paper will try to uncover the historical return of Al-Azhar during the Fatimid Dynasty, history of the establishment, and the factors that affect the educational system.
\end{abstract}

Key Word: Higher Education of Al-Azhar, Fatimiyah, Islamic Civilization.

\begin{abstract}
Abstrak
Al-Azhar merupakan salah satu lembaga pendidikan kebanggaan ummat Islam. Sejarah telah mencatat betapa eksistensi Al-Azhar dari masa awal Dinasti Fatimiyah hingga hari ini menyimpan banyak cerita yang sangat menarik. Tidak hanya itu, Al-Azhar juga berkontribusi sangat besar pada perkembangan peradaban dan intelektual Islam. Banyak ilmuan-ilmuan besar yang lahir dari sana. Satu hal yang tak kalah penting adalah bahwa ternyata sistem pendidikan yang ada di Al-Azhar ternyata di adopsi oleh lembaga pendidikan yang ada di Negara-negara Barat. Oleh karenanya tulisan ini akan coba mengungkap kembali historis Al-Azhar pada masa Dinasti Fatimiyah, sejarah berdirinya, faktor-faktor yang mempengaruhi dan sistem pendidikannya.
\end{abstract}

Kata Kunci: Pendidikan Tinggi Al-Azhar, Fatimiyah, Peradaban Islam. 


\section{PENDAHULUAN}

Berbicara mengenai peradaban Islam seolah tidak pernah ada habisnya, karena selalu menjadi kajian yang menarik ketika diajak menelusuri peninggalan-peninggalan bersejarah dalam Islam. Salah satu kajian itu adalah lembaga pendidikan tinggi Islam Al-Azhar merupakan bukti otentik awal peradaban Islam di masa Dinasti Fatimiyah. Ketertarikan penulis berawal dari maraknya model lembaga pendidikan Islam di masa sekarang ini yang selalu berlomba-lomba menjadi lembaga pendidikan terbaik dengan segala perubahan-perubahannya. Lembaga pendidikan tinggi Islam ikut mewarnai perubahan yang begitu cepatnya di seluruh dunia ini. Katakan saja lembaga pendidikan tinggi Islam di Indonesia, pada era sekarang ini, perubahan itu terlihat secara evolusioner dalam meletakkan kejatidirian lembaga pendidikan tinggi Islam yang profesional dengan berubahnya nama lembaga pendidikan tinggi Islam tersebut dari IAIN (Institut Agama Islam Negeri menjadi UIN (Universitas Islam Negeri).

Perubahan itu membuka kenangan kembali terhadap lembaga pendidikan tinggi Islam Al-Azhar yang tercatat sebagai peradaban Islam yang melahirkan para Intelektual Muslim pada awal kemunculannya pada masa Dinasti Fatimiyah. Sebagai pembaca sejarah tentu saja ingin melihat kejadian pada masa lalu sehingga mampu memberi 'Ibrah (pelajaran) untuk masa sekarang. Hal baik di kejadian masa lalu itu dapat diterapkan dan berdasarkan kerelevanan menjadi bisa dipertimbangkan sebagai bahan kajian. Demikian pula untuk tidak terperosok kedalam lubang yang sama, hal buruk yang pernah terjadi di masa lalu dapat pula di antisipasi. Namun demikian, untuk tidak terjebak dan tenggelam dalam romantika sejarah ummat Islam dituntut untuk selalu melakukan kreativitas dan inovasi dalam segala hal terutama pada lembaga pendidikan Islam. Jika tidak, ummat Islam akan akan semakin ketinggalan dan hanyut terbuai oleh arus sejarah.

Rangkaian paragraf-paragraf berikut ini membahas mengenai awal Al-Azhar sebagai lembaga pendidikan tinggi Islam masa Dinasti Fatimiyah yang memuat tentang; sejarah berdirinya Dinasti Fatimiyah dan kemunculan lembaga pendidikan tinggi Al-Azhar, point-point penting dalam penerapan sistem pendidikannya yang mendukung munculnya peradaban, dan faktor-faktor yang mempengaruhi kejayaan peradaban di dinasti tersebut.

\section{HASIL DAN PEMBAHASAN}

\section{Sekilas Tentang Dinasti Fatimiyah (297-567 H/909-1171 M)}

Dinasti Fatimiyah didirikan sebagai tandingan bagi penguasa dunia muslim kala itu yang berpusat di Baghdad (Dinasti Abbasiyah 750- 
$1258 \mathrm{M})^{1}$ yang secara perlahan mulai melemah. ${ }^{2}$ Nama Daulah Fathimiyah dinisbatkan kepada Fatimah Az-Zahra (putri Nabi Muhammad SAW.) yang juga menjadi istri Ali bin Abi Thalib (sepupu Nabi). Daulah Fatimiyah yang beraliran Syi'ah Isma'iliyah didirikan oleh Ubaidillah alMahdi di Afrika Utara dengan pusat pemerintahannya berkedudukan di Kairawan. ${ }^{3}$ Selama berkuasa lebih kurang 262 tahun wilayah kekuasaan Daulah Fatimiyah mencakup Tunisia, Libya dan Aljazair. Ubaidillah dan para pengikutnya menyebarluaskan ajaran Syi'ah Isma'iliyah secara intensif dan menjadikan ajaran ini sebagai paham resmi kenegaraan. ${ }^{4}$

Para amir/khalifah yang pernah berkuasa pada masa Dinasti Fathimiyah adalah sebagai berikut:

a) Amir Ubaidillah al-Mahdi (910-934 M)

b) Amir al-Qaim Biamrillah (934-945 M)

c) Amir al-Mansur ibn al-Qaim (945-952 M)

d) Khalifah al-Muiz Lidinillah (952-975 M)

e) Khalifah al-Aziz Billah (975-996 M)

f) Khalifah al-Hakim Biamrillah (996-1020 M)

g) Khalifah al-Zahir (1020-1035 M)

h) Khalifah al-Mustanshir Billah (1035-1094 M)

i) Khalifah Musta'li Billah (1094-1101 M)

j) Khalifah al-Amir Biahkamillah (1101-1129 M)

k) Khalifah al-Hafizh Lidinillah (1129-1148 M)

1) Khalifah al-Dhafir Biamrillah (1148-1153 M)

m) Khalifah al-Faiz Billah (1153-1159 M)

n) Khalifah al-Adhid Lidinillah (1159-1171 M). ${ }^{5}$

Dari penjelasan di atas maka jelaslah bahwa Dinasti Fatimiyah merupakan komunitas ahli bait (Keluarga keturunan Rasulullah SAW.) yang didirikan sebagai tandingan terhadap Dinasti Abbasiyah yang penguasa tertinggi ketika itu. Oleh karena itu nuansa Dinasti Fatimiyah sangat kental dengan paham Syi'ah, sebagaimana lazimnya sebuah pemerintahan jika suatu rezim berkuasa maka tujuan pemerintahannya adalah untuk menyebarluaskan ideologinya.

\section{Kondisi Sosial Dinasti Fatimiyah}

Bidang Politik

1 Pemerintahan Abbasiyah ini terdiri dari periode awal tahun 750-847 M, periode lanjutan tahun 847-945 M dan periode Buwaihih tahun 945-1055 M dan periode Saljuk tahun 1055-1258 M.

2 Samsul Munir Amin, Sejarah Peradaban Islam (Jakarta: Amzah, 2009), h. 254. h. 358 .

${ }^{3}$ Faisal Ismail, Sejarah dan Kebudayaan Islam Klasik (Yogyakarta: Diva Press, 2017),

4 Ibid., h. 362.

5 Joesoef Sou'yb, Sejarah Daulat Abasiyah III (Jakarta: Bulan Bintang, 1995), h. 189. 
Para khalifah Dinasti Fatimiyah sangat gencar melakukan ekspansi ke berbagai wilayah. K. Hitti mencatat bahwa kekuasaan Fatimiyah membentang sampai ke Yaman hingga laut Atlantik, Asia kecil dan Mousul. Para khalifah yang berhasil menduduki suatu wilayah akan mengganti nama tempat tersebut dengan nama mereka misalkan, Ubaidillah al-Mahdi mendirikan kota al-Mahdiah di Tunisia, al-Mansur juga mendirikan kota al-Mansuriah, pada masa khalifah al-Mui'z beliau juga mendirikan kota al-Qahirah. ${ }^{6}$

Karena berada di bawah kekuasaan Dinasti Abbasiyah, maka penataan administrasi pemerintahan mengikuti gaya pemerintahan Abbasiyah di Baghdad yaitu kekhalifahan jatuh ke tangan anak khalifah jika ayahnya wafat (monarchy), khalifah juga dibantu oleh wazir atau menteri. Meskipun sangat kental dengan nuansa Syi'ah, orang-orang Sunni juga diberi jabatan sekadar membantu pemerintahan. Sedangkan jabatan tertinggi di pemerintahan umumnya diberikan kepada orangorang Syi'ah. ${ }^{7}$

Agaknya, pemerintahan manapun akan menempatkan seseorang dalam jabatan tertentu yang sepaham dengan ideologi pimpinan. Hal ini bertujuan untuk lebih memudahkan menyamakan persepsi dan mencapai tujuan. Tetapi, yang perlu diingat adalah tidak boleh juga mengabaikan kelompok minoritas, karena mereka juga bagian dari warga negara yang mempunyai hak yang sama. Atas dasar pertimbangan itulah maka orangorang yang berpaham Sunni juga diberikan jabatan sekadar sebagai pembantu bagi pemerintahan Dinasti Fatimiyah yang mayoritas memiliki paham Syi'ah.

\section{Bidang Ekonomi}

Pada masa pemerintahan Dinasti Fatimiyah sumber mata pencaharian masyarakat berasal dari pertanian, industri, dan perdagangan. Mesir merupakan negara agraris yang sangat subur, maka perhatian pemerintah pada sektor pertanian sangat besar sekali. Pemerintah membangun irigasi dari sungai Nil untuk dialirkan ke lahanlahan pertanian. Hasil tanaman ketika itu adalah kurma, gandum, kapas, tebu, bawang dan lainnya. Pada bidang industri menghasilkan tekstil, kain sutra dan wol diekspor ke negara-negara Eropa. Industri kerajinan Mesir menghasilkan karya yang bermutu seperti kiswah Ka'bah yang disulam dengan benang emas, pembuatan kristal dan kramik, mereka juga mendapat income dari hasil tambang besi, baja, dan tembaga. Pada sektor perdagangan mengalami perkembangan pesat dan mendapat dukungan 
dari pemerintah. Para pedagang datang dari berbagai penjuru ke Mesir yang menjadi pusat perdagangan ketika itu. Demikian pula pada sektor pajak yang diperoleh pemerintah mencapai dua juta dinar per tahun. ${ }^{8}$

Tidak bisa dibantah bahwa kondisi ekonomi yang baik akan berpengaruh positif pada keberlangsungan kekuasaan pemerintahan. Terbukti, pada pembahasan berikutnya akan dipaparkan bahwa Dinasti Fatimiyah mampu mendirikan lembaga pendidikan Islam Al-Azhar dengan menghabiskan dana yang cukup besar.

Bidang Pendidikan

Ibn Killis adalah seorang tokoh dan pelopor perkembangan pendidikan pada kekhalifahan Fatimiyah di Mesir. Ia mendirikan sebuah universitas dan menghabiskan ribuan dinar per bulan untuk membiayainya. Salah satu fondasi terpenting yang dibangun pada masa Fatimiyah adalah pembangunan Dar al-Hikmah (rumah kebijaksanaan) atau Dar al-'Ilm (rumah ilmu) yang didirikan oleh al-Hakim pada tahun 1005 M sebagai pusat dan penyebaran ajaran Syi'ah ekstrim. ${ }^{9}$

Perpustakaan Dar al-Hikmah di Kairo didirikan oleh al-Hakim Biamrillah pada tahun $395 \mathrm{H}$. Pada perpustakaan tersebut telah terdapat penanggungjawab, petugas dan karyawan. Perpustakaan itu memiliki 40 lemari, pada salah satu lemarinya terdapat 18.000 buku tentang ilmu-ilmu kuno. Perpustakaan tersebut juga di lengkapi keperluan pengunjung seperti (tinta, pena dan kertas) dan semua orang bebas masuk. ${ }^{10}$ Perpustakaan ini mengoleksi buku-buku di berbagai bidang kesusastraan, ilmu keislaman, ilmu alam, logika, filsafat, dan sebagainya. Hal menarik di era Fatimiyah adalah adanya akademi resmi Negara pertama yang didirikan Khalifah al-Ma'mun dari Dinasti Abbasiyah pada kuartal pertama abad ke-3 H/9 M tidak mendalami ilmu keislaman, melainkan fokus pada penerjemahan karya-karya sains dan filsafat Yunani. Interaksi antara jenis pengetahuan ini dengan keislaman yang berpengaruh besar terhadap peradaban Islam pada masa pertengahan. ${ }^{11}$

Berbagai kegiatan ilmiah diadakan di Dar al-Hikmah dalam bentuk penelaahan, diskusi, mengarang dan menulis buku. Beberapa ilmuan yang aktif di masa ini adalah Abu Hanifah al-Maghribi merupakan seorang ahli agama dari kalangan Syi'ah Isma'iliyah. Dalam bidang sejarah ulama yang terkenal adalah Hasan Ibn Ali bin Zulhaq dan Abu

8 Rahimah, Sejarah Islam di Mesir: Ringkasan Sejarah Pada Masa Fathimiyah dan Napoleon (Medan: USU Digital Library 2003), h. 7.

${ }^{9}$ K. Hitti, History, h. 800.

10 Mustafa Husni al-Siba'i, Min Rawaa'I Hadharatina terj. Abd. Zaky al-Kaaf, dengan judul Khazanah Peradaban Islam (Bandung: Pustaka Setia, 2002), h. 207.

11 Fazlur Rahman, Islam: Sejarah Pemikiran dan Peradaban Terj. M. Irsyad Rafsyadie (Bandung: Mizan Media Utama, 2017), h. 275. 
Hasan Ali al-Syabsyata. Dalam bidang filsafat muncul ulama terkenal seperti al-Razi, al-Kindi, Abu Ya'qub, Ja'far Ibn Mansur. Kemudian bidang kedokteran muncul ulama Abu Abdullah, tokoh matematika Abu Ali Muhammad al-Haitami, tokoh astronomi Ali bin Yunus dan Jiz bin Yunus. Ahli optik yang menulis buku tentang penyakit mata ke dalam bahasa latin adalah Ibn Haitami dan al-Hazan dengan bukunya alManazir, Amri Ali dengan bukunya al-Muntakhab fi 'Ilaj al-'Aini. Tokoh yang muncul di bidang sastra adalah Abu al-Hamid al-Anthaqi, Ibn Hani, Ibn Abi Jar, Abu Hamid Ahmad, dan Abdul Wahab Ibn Nashr. ${ }^{12}$

Dari paparan di atas tampak jelas bahwa kemajuan dibidang pendidikan pada masa Dinasti Fathimiyah sangat berkembang pesat. Kemunculan berbagai tokoh dan penemu tidak hanya pada bidang agama saja, tetapi juga pada bidang ilmu-ilmu umum. Pada masa ini juga terjadi kontak dengan Barat melalui penerjemahan buku-buku Yunani ke dalam bahasa Arab. Hal ini menambah kepercayaan kita bahwa semangat keilmuan dan tradisi intelektual ketika itu sangat luar biasa.

\section{Sejarah Berdirinya Lembaga Pendidikan Tinggi Al-Azhar}

Universitas Al-Azhar atau lembaga pendidikan tinggi Al-Azhar didirikan pada tahun $359 \mathrm{H} / 970 \mathrm{M}$ pada masa pemerintahan al-Mu'iz Lidinillah (952-975 M) dari Dinasti Fatimiyah dan selesai dibangun pada tahun $361 \mathrm{H} / 971$ M.13 Universitas ini dahulu adalah sebuah masjid yang digunakan untuk tempat shalat dan ibadah lainnya, khususnya ketika Dinasti Fatimiyah berkuasa, masjid ini digunakan sebagai sarana penyebarluasan paham Syi'ah. Pada awal berdirinya masjid ini diberi nama Jami'ul Kahhirah (Kairo) karena mengambil nama tempat universitas tersebut didirikan, Belakangan, namanya diubah menjadi Al-Azhar mengikuti nama putri Rasulullah SAW.

Masjid Al-Azhar merupakan pusat ilmu pengetahuan, tempat diskusi bahasa, dan mendengarkan kisah dari orang-orang yang ahli bercerita. Masjid ini diperuntukkan bagi Dinasti Fatimiyah yang merupakan sarana diskusi sebagaimana kekhalifahan Abbasiyah memperlakukan masjidnya di Baghdad. Usaha yang dilakukan adalah mengajarkan mazhab Syi'ah kepada kader-kader muballigh yang bertugas meyakinkan masyarakat akan kebenaran mazhab yang dianutnya. ${ }^{14}$ Perkembangan diskusi mengalami perkembangan hanya sebagai informasi mazhab berkembang menjadi informasi keilmuan.

12 Rahimah, Sejarah, h. 8.

13 Dewan Redaksi, Ensiklopedi Islam (Jakarta: Ikhtiar Baru Van Hoeve, 2003), h. 200.

14 Muhammad Atiyah al-Abrasyi, Dasar-Dasar Pokok Pendidikan Islam (Jakarta: Bulan Bintang, 1993), h. 61. 
Kemunculanya Al-Azhar sebagai lembaga pendidikan tinggi bermula ketika khalifah al-Mu'iz Lidinillah pada tahun $362 \mathrm{H} / 973 \mathrm{M}$ memindahkan ibu kota Daulah Fatimiyah dari kota Qairawan (Tunisia) ke kota al-Qahirah (Kairo/Mesir), dan pada tahun $975 \mathrm{M}$ ia meresmikan berdirinya perguruan Al-Azhar. ${ }^{15}$ Sudah tentu tujuan pendirian Al-Azhar semata-mata karena dorongan untuk melestarikan dan mengembangkan mazhab yang dianut oleh khalifah tersebut. Namun seiring waktu perkembangan itu meyakinkan terjadinya proses pembelajaran di tingkat dewasa. Nuansa keilmuan yang marak dalam lembaga pendidikan tinggi Al-Azhar tersebut menjadikan tata kelola pendidikannya mendapat perhatian dari khalifah Dinasti Fatimiyah agar diatur secara profesional.

\section{Sistem Pendidikan pada Lembaga Pendidikan Tinggi Al-Azhar}

\section{Tujuan Al-Azhar}

Universitas Al-Azhar pada masa Dinasti Fatimiyah merupakan lembaga pendidikan yang menjadi corong dan alat untuk propaganda kekuasaan kekhalifahan sekaligus sebagai alat penyebaran Doktrin Syi'ah. ${ }^{16}$ Sebagaimana yang kita maklum bahwa di mana rezim berkuasa di situ pula ideologi mereka disebarkan melalui berbagai macam cara, tidak terkecuali pendidikan. Mahmud Yunus mencatat bahwa ada lima tujuan dari universitas Al-Azhar ketika itu:

a) Mengemukakan kebenaran dan pengaruh turas (peradaban) Islam terhadap kemajuan ummat manusia dan jaminannya terhadap kebahagiaannya didunia dan akhirat.

b) Memberikan perhatian penuh terhadap peradaban ilmu, pemikiran dan keruhanian bangsa Arab Islam.

c) Menyuplai dunia Islam dengan ulama-ulama aktif yang beriman, percaya terhadap diri sendiri, mempunyai keteguhan mental dan ilmu yang mendalam tentang akidah, syariat dan bahasa al-Quran.

d) Mencetak ilmuwan agama yang aktif dalam semua bentuk kegiatan, karya, kepemimpinan dan menjadi contoh yang baik serta mencetak ilmuwan dari berbagai ilmu pengetahuan yang sanggup aktif dalam berdakwah Islam yang dipimpin dengan hikmah dan kebijaksanaan dan pelajaran yang baik di luar dan di dalam Republik Arab Mesir.

\footnotetext{
${ }^{15}$ Abdul Sani, Lintasan Sejarah Pemikiran: Perkembangan Modern Dalam Islam (Jakarta: Rajawali Press, 1998), h. 200.

${ }^{16}$ Asriati Amaliyah, "Eksistensi Pendidikan Islam di Mesir Pada Masa Daulah Fatimiyah", dalam Lentera Pendidikan, Vol. XVI, h. 105.
} 
e) Meningkatkan hubungan kebudayaan dan ilmiah dengan universitas dan lembaga ilmiah Islam di luar negeri. ${ }^{17}$

Para Pendidik di Al-Azhar

Pada tahun $365 \mathrm{H} / 975 \mathrm{M}$ untuk pertama kalinya dimulai kegiatan ilmiah dalam bentuk kuliah-kuliah yang diberikan oleh Abu Hasan Ali Ibn Muhammad Ibn Nu'man al-Qairani yang menjabat sebagai hakim tertinggi (qadi al-qudat). dengan materi yang diajarkan mengenai fikih syari'ah yang terdapat dalam kitab al-Ikhtisar. ${ }^{18}$ Ada ulama yang sangat rajin mengajarkan mazhab Syi'ah adalah Ibn Killis. Diantara ulama yang cukup terkenal sebagai pengajar di Al-Azhar ketika itu adalah Al-Aqabah Abu Ya'kub al-Khandaq. Menurut catatan Salah Zaimeche bahwa Ibnu An-Nurul dan Ibn Khaldun juga ikut serta menjadi pengajar di universitas Al-Azhar sampai akhir abad keempat. ${ }^{19}$

\section{Peserta Didik}

Al-Azhar sebagai lembaga pendidikan tinggi ketika itu, telah banyak melahirkan ulama yang tidak diragukan lagi dari aspek keilmuannya dan telah banyak menyumbangkan khazanah ilmu pengetahuan terutama dalam bidang ilmu-ilmu keislaman, baik dari Mesir maupun ulama yang berasal dari daerah lainnya. Di antara mereka ialah Izuddin Abdissalam, Imam Subki, Jalaluddin as-Syuyuti, al-Hafiz Ibn Hajar al-Asqalani dan lainnya. ${ }^{20}$ Al-Maqrizi menyebutkan bahwa pada saat itu ada 750 mahasiswa asing yang berasal dari Magribi (Maroko) dan Persia turut serta belajar ke universitas Al-Azhar. ${ }^{21}$

\section{Kurikulum}

Salah Zaimeche mencatat bahwa, selain mengajarkan mata pelajaran agama dan sastra tradisional, Al-Azhar juga mengajarkan geografi, astronomi, kedokteran, teknik dan matematika. ${ }^{22}$ Sementara menurut Asriati Amalia, kurikulum di universitas Al-Azhar pada awalnya hanya fokus kepada ilmu agama dan ilmu akal (logika)23. Ilmu-ilmu agama meliputi al-Quran, tafsir, hadits, ilmu kalam, fiqih, dan tasawuf. Sedangkan ilmu-ilmu logika dan umum meliputi filsafat, kedokteran, optik, astronomi, matematika, sejarah, dan sastra. Pada masa pemerintahan Dinasti Fatimiyah juga sangat gencar dilakukan

17 Mahmud Yunus, Sejarah Pendidikan Islam (Jakarta: Hidyakarya Agung, 1990), h.

\footnotetext{
18 Abdul Sani, Lintasan, h. 200.

${ }^{19}$ Salah Zaimeche, Cairo (United Kingdom: FSCT Limited, 2005), h. 10.

${ }^{20}$ Mahmud Yunus, Sejarah, h. 176.

21 Salah Zaimeche, Cairo, h. 10.

22 Ibid.

${ }^{23}$ Amaliyah, Eksistensi Pendidikan. h. 105.
} 
penerjemahan buku-buku asing ke dalam bahasa Arab. Pada awalnya hingga beberapa dekade sesudahnya sistem pendidikan dan kurikulum di universitas Al-Azhar relatif tidak berubah sejak awal yaitu tidak ada persyaratan khusus untuk masuk ke universitas ini, kurikulumnya tidak resmi, dan tidak memberikan gelar kepada alumninya. Program studi dasar adalah hukum Islam, theologi Islam, hadits, al-Quran dan bahasa Arab. ${ }^{24}$

\section{Metode Pengajaran}

Pada mulanya pengajaran di universitas Al-Azhar sama dengan institusi pendidikan yang lain, yaitu sistem halaqah (melingkar). Seorang pelajar bebas memilih guru dan pindah sesuai dengan kemauannya. Umumnya guru atau syaikh yang mengajar duduk bersama para pelajar, tetapi kadang-kadang duduk di kursi ketika menerangkan kitab yang diajarkannya. Di samping itu, metode diskusi sangat dikembangkan sebagai metode dalam proses pembelajaran antar pelajar. Seorang guru hanya berperan sebagai fasilitator dan memberi penajaman dari materi yang didiskusikan. ${ }^{25}$

Terdapat tiga kelas sebagai tempat pembelajaran di Al-Azhar. Tempat pertama adalah kelompok orang-orang yang datang ingin belajar al-Quran, di tempat yang kedua, murid-murid duduk melingkar di lantai, sementara sang guru duduk di atas kursi yang agak rendah lalu mendiktekan pelajaran kepada para siswa, kemudian menjawab pertanyaan dari siswa. Pada tempat yang ketiga, para murid belajar dengan cara berhadapan langsung secara mandiri antar teman, di mana yang berperan sebagai guru adalah dari kalangan mereka sendiri yang telah ditentukan oleh pimpinan Al-Azhar. ${ }^{26}$

Secara rutin juga diadakan ceramah pengkajian tentang nasehatnasehat bijak setiap hari senin yang terbuka untuk umum. Sedangkan pada hari kamis khusus untuk kelompok tertentu. Kebanyakan mereka melaksanakan pengajian di halaman depan istana, ada juga sebahagian yang mengadakan pengajian khusus bagi wanita di dalam gedung AlAzhar. Demikian juga sebahagian laki-laki mengadakan pembelajaran di dalam gedung. ${ }^{27}$

Bahasa yang digunakan oleh para pengajar sangat baik dan puitis sesuai dengan kondisi pendengarnya. Materi disampaikan dalam bentuk

24 Wan Kamal Mujani, et. al., "The Role of Al-Azhar University in The Dissamination of Islamic Religious Knowledge in Malaysia", dalam Advances in Natural and Applied Sciences, Vol. VIII, h. 1411.

${ }^{25}$ Mahmud Yunus, Sejarah, h. 96.

${ }^{26}$ Bayard Dodge, Al-Azhar: A Millenium of Muslim Learning (Washington DC: The Midle East Institute, 1961), h. 17.

27 Ibid. 
pidato singkat dan efektif untuk diikuti dan didiskusikan secara informal. Meskipun materi utama yang disampaikan berhubungan dengan moral dan hukum-hukum al-Quran, akan tetapi setiap mereka (para pengajar) menggunakan kiasan dan penafsiran yang secara tidak langsung mengarahkan pendengar mengikuti idiologi khalifah Dinasti Fatimiyah. Pada akhir pembelajaran mereka (para murid) masing-masing berdiri dan mencium tangan guru. ${ }^{28}$

\section{Sarana Prasarana}

Untuk menunjang kegiatan pendidikan dan pengajaran, Al-Azhar dilengkapi dengan asrama untuk para fuqaha (dosen, tenaga pendidik) serta semua urusan dan kebutuhannya ditanggung oleh khalifah. ${ }^{29}$ AlAzhar juga menyediakan asrama bagi mahasiswa yang belajar di sana secara gratis, sementara bagi mahasiswa yang memiliki kemampuan ekonomi yang lebih, mereka tinggal di penginapan yang lebih bagus dan dekat dengan masjid. ${ }^{30}$ Fasilitas lainnya adalah dapur dan toilet serta perpustakaan dengan komposisi buku yang memadai, tidak hanya bukubuku yang berhasa Arab tetapi juga buku-buku terjemahan dari Yunani.

Dari berbagai paparan terdahulu, maka tampak jelas bahwa sistem pendidikan Al-Azhar sebagai lembaga pendidikan tinggi Islam yang tertua, memiliki dampak yang besar terhadap pertumbuhan lembaga pendidikan sesudahnya. Hal ini dikarenakan sistem pendidikan yang ada di Al-Azhar dahulu hingga saat ini banyak diadopsi oleh lembaga pendidikan Islam dan lembaga pendidikan umum lainnya. Oleh karena itu sebenarnya lembaga-lembaga pendidikan kontemporer berhutang banyak kepada para pendiri Al-Azhar.

Sistem pendidikan yang baik dan maju pada masa Dinasti Fatimiyah dapat menjadi penunjang terhadap kemajuan peradaban Islam. Kemajuan peradaban ini karena adanya dukungan dari sistem politik yang aman, sistem ekonomi yang stabil, sistem sosial yang nyaman sehingga pergolakan pemikiran menjadi tumpuan dalam menciptakan komunitas yang berperadaban. Kegairahan dalam menuntut ilmu dan memajukan pengetahuan mewujudkan lahirnya para intelektualintelektual Muslim pada masa Dinasti Fatimiyah ini. Karya-karya para intelektul masa ini memenuhi perpustakaan-perpustakaan yang didirikan di daerah kekuasaan Dinasti Fatimiyah ini.

\section{Faktor yang Menunjang Kejayaan Peradaban Dinasti Fatimiyah}

Paparan Dinasti Fatimiyah sebagai satu kekuatan pemerintahan telah melakukan puncak kegemilangan yang tidak diragukan dengan

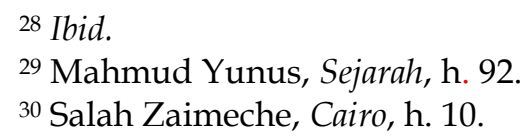


berdirinya lembaga pendidikan tinggi Al-Azhar. Selain lembaga pendidikan ini Dinasti Fatimiyah memiliki kekuatan misi dalam mengembangkan ajaran Syi'ah Isma'iliyah. Ajaran ini dikembangkan di dalam proses pembelajaran yang ada di berbagai lembaga pendidikan yang ada di masa Dinasti Fatimiyah tersebut. Misi ini menjadi kekuatan bagi Dinasti Fatimiyah untuk mengembangkannya menjadi lebih eksis di daerah kawasan kekuasaannya. Motivasi yang tinggi diwujudkan para pemimpin dinasti ini untuk menjaga kestabilan negara sehingga mampu meraih peradaban yang cukup diperhitungkan dalam membangun intelektual muslim yang cemerlang.

Dengan demikian jika dicermati dari perjalanan Dinasti Fatimiyah, disebutkan dalam disertasi Heinz Halm $^{31}$ bahwa faktor yang membawa kejayaan peradaban adalah missi ajaran dinasti yang penuh dengan semangat untuk menyebarkannya sehingga tercipta proses tradisi pembelajaran materi kesyi'ahan. Para da'i Syiah sangat giat menyebarkan paham ini dalam segala cara sehingga doktrin ini dapat diterima di masyarakat yang notabane Sunni di Mesir.

Faktor lainnya adanya para pemimpin dari Dinasti ini memiliki kegairahan akan ilmu pengetahuan setelah terlihatnya Dinasti Abbasiyah yang maju dalam peradabannya maka dinasti Fatimiyah mendirikan lembaga pendidikan tinggi selain mengkaji materi kesyi'ahan juga mengembangkan materi ilmu-ilmu sains yang dikembangkan dalam pendirian observatorium yang sangat lengkap. ${ }^{32}$ Semangat pemimpin Dinasti Fatimiyah ini juga melakukan pengumpulan naskah-naskah di perpustakaan yang didirikan serta institusi-institusi lainnya yang dapat menunjang peradaban Islam seperti dar al-Hikma, dar al-Ilmu, dan dar alIlmu al-Jadida dan institusi dewan dakwah lainnya seperti da'wat alHagg, da'wa al-hadiya. Begitu juga dengan pendirian madrasah maupun majelis-majelis keilmuan lainnya berkembang secara marak dan mendapat dukungan penuh dari pemerintahan dinasti Fatimiyah. Kekayaan Dinasti ini betul-betul disumbangkan untuk peningkatan peradaban Islam sehingga menjadi mercusuar warisan Islam hingga kini.

\section{PENUTUP}

Universitas Al-Azhar yang didirikan pada tahun 359 H/970 M adalah masa pemerintahan Dinasti Fatimiyah dengan kepemimpinan alMu'iz Lidinillah dan berakhir pembangunan tersebut pada tahun $361 \mathrm{H} /$ 971 M. Pada awal universitas Al-Azhar adalah masjid yang diberi nama Jami'ul Kahhirah (Kairo) karena mengambil nama dari tempat asal

${ }^{31}$ Heinz Halm The Fatimids and their Tradition of Learning, London; I.B Tauris \& Co.Ltd, 1997, hlm. 17 .

32 Ibid., hl. 87. 
universitas tersebut didirikan. Belakangan, namanya diubah menjadi AlAzhar mengikuti nama putri Rasulullah SAW. Berdirinya universitas menunjukkan kondisi perkembangan sistem politik, sosial, ekonomi sangat stabil, sehingga kemajuan ilmu pengetahuan menjadi fokus untuk dikembangkan. Selain itu juga pengembangan faham sebagai misi dan visi Dinasti ini dilakukan proses penyebaran dengan mengajarkannya di universitas tersebut, sehingga segala sesuatunya diatur secara sistematis.

Al-Azhar pada masa Dinasti Fatimiyah merupakan lembaga pendidikan yang menjadi corong dan alat untuk propaganda kekuasaan kekhalifahan sekaligus sebagai alat penyebaran doktrin Syi'ah. Universitas Al-Azhar mengajarkan ilmu agama (al-Quran, tafsir, hadits, ilmu kalam, fiqih, dan tasawuf) dan ilmu akal atau logika (filsafat, kedokteran, optik, astronomi, matematika, sejarah, dan sastra). Adapun metode pembelajaran yang digunakan adalah dengan menggunakan sistem halaqah dan diskusi. Al-Azhar menyediakan fasilitas berupa asrama bagi para pengajar dan mahasiwa. Sarana lainnya adalah dengan menyediakan perpustakaan yang menyediakan beragam buku-buku terjemahan dari Barat. Aktivitas yang tinggi dalam proses pendidikan di lembaga pendidikan tinggi Al-Azhar serta tata pengelolaan lembaganya yang teratur.

Faktor kejayaan peradaban Islam di masa Fatimiyah selain karena misi keagaman tetapi juga ghirah pendidikan. Tokoh-tokoh yang terlibat dalam pengembangan ilmu pengetahuan dengan melahirkan karya-karya yang banyak dapat menjadi pengkajian Keilmuan Sejarah Islam. Di antara nama-nama guru Al-Azhar pada masa Dinasti Fatimiyah adalah Abu Hasan Ali Ibn Muhammad Ibn Nu'man al-Qairani, Ibn Killis dan alAqabah Abu Ya'kub al-Khandaq. Sedangkan di antara peserta didik yang pernah belajar di Al-Azhar adalah Izuddin Abdissalam, Imam Subki, Jalaluddin as-Syuyuti, al-Hafiz Ibn Hajar al-Asqalani dan lainnya. Kehadiran tokoh-tokoh ini menjadi penghantar terhadap kejayaan Intelektual Muslim dengan tekad yang kuat sehingga mengalami kejayaan peradaban Islam di masa sekarang.

\section{DAFTAR PUSTAKA}

al-Abrasyi, Muhammad Atiyah. Dasar-Dasar Pokok Pendidikan Islam. Jakarta: Bulan Bintang, 1993.

al-Siba'i, Mustafa Husni. Min Rawaa'I Hadharatina terj. Abd. Zaky al-Kaaf, dengan judul Khazanah Peradaban Islam. Bandung: Pustaka Setia, 2002. 
Amaliyah, Asriati. "Eksistensi Pendidikan Islam di Mesir Pada Masa Daulah Fatimiyah." Lentera Pendidikan Vol. XVI (2013).

Amin, Samsul Munir. Sejarah Peradaban Islam. Jakarta: Amzah, 2009.

Dewan Redaksi. Ensiklopedi Islam. Jakarta: Ikhtiar Baru Van Hoeve, 2003.

Dodge, Bayard. Al-Azhar: A Millenium of Muslim Learning. Washington DC: The Midle East Institute, 1961.

Halm, Heinz. The Fatimids and Their Tradition of Learning. London: I.B Tauris \& Co.Ltd., 1997.

Hitti, Philip K. History of The Arabs. Jakarta: PT Serambi Ilmu Semesta, 2008.

Ismail, Faisal. Sejarah dan Kebudayaan Islam Klasik. Yogyakarta: Diva Press, 2017.

Rahimah. Sejarah Islam di Mesir: Ringkasan Sejarah Pada Masa Fathimiyah dan Napoleon. Medan: USU Digital Library, 2003.

Rahman, Fazlur. Islam: Sejarah Pemikiran dan Peradaban Terj. M. Irsyad Rafsyadie. Bandung: Mizan Media Utama, 2017.

Sani, Abdul. Lintasan Sejarah Pemikiran: Perkembangan Modern dalam Islam. Jakarta: Rajawali Press, 1998.

Sou'yb, Joesoef. Sejarah Daulat Abasiyah III. Jakarta: Bulan Bintang, 1995.

Wan Kamal Mujani, et.al. "The Role of Al-Azhar University in the Dissamination of Islamic Religious Knowledge in Malaysia." Advances in Natural and Applied Sciences Vol. VIII (2012).

Yunus, Mahmud. Sejarah Pendidikan Islam. Jakarta: Hidyakarya Agung, 1990.

Zaimeche, Salah. Cairo. United Kingdom: FSCT Limited, 2005. 